\title{
UNIVERSALIST FEMINISM IN THE FIELD OF AUTHORSHIP (A CASE STUDY ON SIDOARJO WOMEN WRITERS COMMUNITY)
}

\author{
${ }^{a}$ Niko Fediyanto, ${ }^{b}$ Vidya Mandarani, ${ }^{c}$ Yuli Astutik \\ a,b,c Universitas Muhammadiyah Sidoarjo \\ e-mail: nikofediyanto@umsida.ac.id
}

\begin{abstract}
This research discusses the community of women writers in Sidoarjo using a feminist sociological perspective. The purpose of this research is to formulate the pattern of relations of this community with the structure of the field of authorship using Bourdieu's perspective. The research method used is qualitative with descriptive patterns. Data were collected using a combination of interview and documentation techniques using library research procedures. The results showed that this community of women writers had an awareness of the existence of dominant-dominated binary opposition structures and included aspects of gender considerations in their authorship strategies, but they chose patterns as used in universalist feminism.
\end{abstract}

Keywords: women writers, dominant-dominated, social structure. 


\section{INTRODUCTION}

Writing is a flowing process that requires habituation by involving mental processes but generally remains results-oriented. The formation of writing skills often requires a supporting structure so that one's writing skills can be established. There are various ways for a person's writing ability to be established, starting from processes that involve formal education, non-formal education, to the independent process in groups. The last point mentioned is one of the phenomena that emerged several decades ago and still exists today.

This research discusses the process of achieving the writing ability of a writing community in Sidoarjo. This writing community has a specific character, which is that they limit their membership to only women. This, according to the researchers, is an interesting object of study because there are a number of specific driving factors that are the foundation of community development, i.e., gender factor.

The use of the writing community platform as the main foundation for achieving writing establishment skills is not something new in Indonesia. In fact, in Sidoarjo, there are other writing communities, such as the Lingkar Pena Forum (FLP) and several other independent communities.

The researchers included this study in the category of a sociological literature study. The gender perspective is used as an analysis tool because the object of this study is a community consisting of individuals with social attachments. Meanwhile, the second perspective, namely the meta-literary study, was made the second perspective because the Sidoarjo women's writers community uses literature as a genre that they generally use.

The use of sociological perspectives in literature and meta-literature is no longer a strange and relevant matter for debate. (Salam \& Anwar, 2015) said that starting in the 2000s, literary research was no longer focused solely on intrinsic and textual aspects in the works, but on external aspects, such as sociology. This is necessary because, in a larger scope, literature, as a product, cannot be separated from the process. There is a large framework consisting of various small fragments in the production of literary works, ranging from writers, readers, communities, and even the printing producers and publishers involved.

When viewed from the context of authorship, the activities undertaken by this community of female writers can be categorized in creative writing activities. This relates to the focus of writing, which revolves around literary products and other creative writing. (Harper, 2010) stated that the creative writing process, in general, involves two discussions, which is the creative writing process and the results of the creative writing process.

(Harper, 2010) continued that another important aspect of creative writing is that this term is used to describe a production process that is not merely a "production" process. Creative writing cannot be compared to the process of producing goods in general, which can be seen solely from an economic perspective. The reason is that there is an interest in the fulfillment of non-material needs.

There is an economic process involved in creative writing, but economic goals cannot be considered as the main goal because the writers tend not to consider their work as a commercial object. This also happened to be discovered by researchers in the Sidoarjo Women's Writers Community.

This community consists of 19 women who are, on average, non-professional writers with no economic dependence on the results of their writing products. All members are women with a medium socio-economic profile. This factor prevents them 
from putting the mission of producing "economic goods" as a goal in their writing process.

This research is not a justification tool to classify the characteristics of writing of women writers in this community, but as a study to look for patterns in the path of this community to gain recognition in the world of writing by using a gender perspective. Rather, this research seeks to look for aspects of the benefits of class distinction that can be used as "capital" (borrowing a term coined by (Bourdieu, 2001)) in the authorship field.

The main problem that attracts researchers to find out more about this community is the gender classification factor, i.e., membership restrictions, which are limited to women. This is clearly interesting because the community can open up opportunities for their membership from any class/gender. This problem is then formulated into two questions. First is what gender factors have influenced this community. The second is how the gender factor works in the social construction of greater authorship outside this community.

Moving on from this problem and formulation of the problem, the researchers sought to formulate goals that had a contribution to the academic world in Indonesia. The first objective is to have a new reference for writing strategies related to gender. Creative writing, especially literary writing, cannot merely be understood as a production of aesthetic goods, but also understood as a process that requires a strategy and understanding of cultural production maps.

The second objective in making this article is a recommendation on the development of writing strategies for the women's writers group in Sidoarjo and other writing groups in general. During this time, the study of female writers is more inclined to issues related to gender issues. Meanwhile, sociological studies of writers and authorship strategies tend to refer to writers who are consecrated. In fact, writing strategies are more likely to be needed by novice writers who do not yet have a relatively narrow perspective on the field of cultural production.

\section{RESEARCH METHOD}

The method used as an analysis tool in this research is descriptive qualitative. According to (Denzin \& Lincoln, 2005), qualitative research is a situated activity that places the observer in the world. Qualitative research support tools include a set of interpretive, material practices that enable the researcher to see the world.

(Denzin \& Lincoln, 2005) also said that the data in qualitative research could be extracted from field notes, interviews, conversations, photographs, recordings, and memos to the self. The world is approached using interpretive, naturalistic techniques that provide a way for researchers to explore information in their natural settings, attempting to make sense of, or to interpret, phenomena in terms of the meanings people bring to them.

This research is in the descriptive category because it is in accordance with the opinions, the main purpose is to describe and explore the understanding and interpretation of the subject of the phenomena that exist in social life (Ritchie \& Lewis, 2003). This is used to carry out deep excavations.

Primary data collected in this study were obtained directly from research subjects, while secondary data, which are supporting data, were collected from other sources, such as libraries. 
The researcher applied two techniques, which are:

a. In-depth Interview

The key feature of this mode of an interview is that it provides in-depth data and detailed investigation

b. Documentation

Researchers obtain secondary data from documents related to the problem under study. These documents are mostly in the form of sources/literature in previous studies that provide relevant descriptions without limited time and place.

The subjects in this study were chosen as a whole because all the writers in the community were involved.

\section{DISCUSSION}

\section{A. Women Writers in Indonesia}

(Wiyatmi, 2008) showed that female writers in Indonesia have indeed appeared since the colonial era, but the rise of new female writers occurred around the 2000s. In the colonial period, writers, especially literature, were dominated by men. Some female writers do continue to exist from the beginning of the 20th century until the 21 st century, but their numbers tend to be small compared to male writers.

Based on her search, (Wiyatmi \& Yogyakarta, 2008) noted that in the 1930s, Selasih (1908-1995) had written her work Pengaruh Keadaan (1937), and then there was Fatimah Hasal Delais with Kehilangan Mestika (1935), Suwarsih Djojopuspito with Manusia Bebas (1975), Arti Purbani (Ny. Husein Djajadiningrat, Widyawati, 1949), Nursiah Dahlan (Arni, 1953). Zunaidah Subro also wrote Patah Tumbuh Hilang Berganti (1953), and then Johanisun Iljas (Anggia Murni, 1956) and Waluyati Supangat (Pujani, 1951). In the 1970s, there was Nh. Dini who was extremely productive with several novels like Hati yang Damai (1961), Pada Sebuah Kapal (1973), La Barka (1975), Keberangkatan, 1977, Namaku Hiroko (1977), Orang-orang Tran (1985), Pertemuan Dua Hati (1986), Jalan Bandungan (1989), and also Tirai Menurun (1994).

Next, there were new names in prose writing genres such as Aryanti, Lilimunir C, Maria Sugiharto, Titis Basino, Marianne Katoppo. In Poetry, there were Mariamin, Isma Sawitri, Poppy Dongo Hutagalung, Rayani Sri Widodo, Toeti Heraty. Their works were collectively published in Selendang Pelangi with Toeti Heraty as the editor (Wiyatmi \& Yogyakarta, 2008).

This long list shows that female writers have always existed since colonial times, but the percentage is clearly still far less than male writers. In the 2000s, the appearance of female writers tended to increase. A number of writers, such as Djenar Mahesa Ayu, Ayu Utami, and Dewi Lestari, produced several novels that received a warm response from readers. However, according to (Wiyatmi, 2008), patriarchy still shows its repression with negative responses (which tend to demean) female writers, so it can be concluded that female writers and their works still do not get the same place as men's works in modern Indonesian literature.

The perceptions of patriarchal dominance in the world of authorship were also written by (Widayani \& Hartati, 2015). They highlighted the perception of female writers on gender equality and justice in Bali. The results of this study may be rather specific because they discuss Balinese culture, which is relatively strict with aspects 
of culture and tradition. However, this reference can be used as a reflection of the social structure in terms of gender in Indonesia because, in general, culture and customs become one of the biggest umbrellas that makes patriarchy dominant in various social communities in Indonesia.

(Widayani \& Hartati, 2015) concluded that Balinese women represented by these female writers have different external factors, but are similar. The difference is in their responses or perceptions, but each view is influenced by similar factors, namely the process of each subject (female writer) in experiencing the process of forming self-concepts, assessments of the environment such as views of Balinese women themselves, families and children; adjustment, beliefs, and future expectation.

\section{B. Women's Community, Feminism, and The Structure of Cultural Production}

Although it is not an unfamiliar name in literary-related studies, Pierre Bourdieu may not be the name that usually appears in gender studies, especially in the study of feminism related to literature. However, Burdieu actually also included gender differences in one of his studies in the Qubail community, which was recorded in Masculine Domination (Bourdieu, 2001). (Salam \& Anwar, 2015) formulated Bourdieu's perspective as a constructivist structuralist because Bourdieu stated that in the social world there are objective structures independent of agent's consciousness and will. This is something that is able to direct and hinder the practice or representation of agents. Bourdieu's constructivism can be seen from the existence of two branched social origins, namely the origin of a scheme of perception, thought, and action that forms what is called habitus, and the origin of a social structure, specifically what is called as the arena/ field.

Bourdieu's main focus in his various concepts laid social structural classification as a fundament which was then influenced by various other factors that were more specific. (Swartz, 1997) writes that other specific factors called "classes" include groups of workers, parents, and women. That is, physical binary opposition between men and women in social life is inevitably one of the foundations for social class.

(Swartz, 1997) also stressed that Bourdieu rarely provided really detailed classifications and definitions of these specific factors. However, it is clear that these factors play an important role in social classification, as he did in observing the distinction of working class women and peasants in France in the 1980s. Relations that arise in intergender relations in Bourdie's social classification, according to Swar, are related to power. The more dominant social groups are groups that have the potential to become dominant because they have more power. On the other hand, (Musarrofa, 2019) suggested that the sociological framework offered by Bourdieu could be very instrumental in exposing gender inequality in society. She proposed that Pierre Bourdieu's analysis provides the foundation of a basic understanding of the meaning of society of symbols that represent differences between men and women. In the field of cultural production, women writers are also classified in to "dominated writers" by (Bourdieu, 1993)

Studies by (Wiyatmi \& Yogyakarta, 2008), (Arimbi, 2014), and (Widati, 2009) showed that in many perspective, gender has always been related to the dominant group power anr repression, i.e., the patriarchy. In contrast to (Wiyatmi \& Yogyakarta, 2008), (Arimbi, 2014) showed that gender has been a serious issue since the colonial era (in 1920s) and that women have always made efforts in fighting the repression of dominant power. The indication of women struggle and feminism has also been "kicking" the domination of patriarchy in Java, as shown by (Widati, 2009). 
Based on these findings, it can be generalized that the world of authorship in a small scope such as Sidoarjo is inseparable from dominance. Related to the subject in this research which is a female community, the dominance that arises in the world of authorship is related to patriarchy. In the social structure, this women's community has similarities to the categories of women judges mentioned by (Wiyatmi, 2008), and their identities as women are not much different from the identities of women reflected through the various works analyzed by (Arimbi, 2014) and (Widati, 2009). In general, the position of the Sidoarjo women's writer community is in a dominated position.

However, in terms of feminism, this cannot simply be said that the movements they undertake have a feminist mission. Based on data collected by the researchers, this community stated that the purpose of establishing this community was a forum / community that was simply established because of the same mission. Although members of this community come from different backgrounds (which also allows them to have varied socio-economic backgrounds), they have the same problem, namely the blockage of creativity. Despite having different professions, they have some of the same habits and are considered unproductive, such as gossiping and wasting a lot of time waiting for children at school. These, according to the researchers, are some of the characteristics of women in urban areas such as Sidoarjo. In general, this situation is present in most housewives because these activities are one of the responsibilities of female households even though they have a status as a career woman.

Seeing the characteristics of the motives underlying this community formation, as stated above, it cannot be said that this community is a feminist movement. However, it also cannot be ignored that such patterns are a reflection of the dominance and dominance of the femomena in a social structure, and may even provide a solution to the gender equality movement in Indonesia, particularly those related to authorship. What is done by this community of women writers can be categorized as a movement called (Bourdieu, 2001) as feminist universalism. This relates to several characteristics that exist in this community of women writers, such as:

a. They ignore the dominance and effect of domination and their position as dominated in the field of authorship.

b. They focus on authorship and positivistic reasoning with the spirit of "art for art".

However, this neglect is not a form of ignorance because based on the results of interviews, the community is fully aware that they need a strategy to stay in the field of authorship. When writers do the writing process, they are bound to a procedure that requires the brand to go through the stages of curation by writers who have been consecrated / have legitimacy. In this process, all processes from writing to curation are carried out by women. In accordance with the data obtained, this legitimate female writer also has to curate the writings of several other communities which are also the writers' community. 


\section{CONCLUSION}

The women's writers community in Sidoarjo is a forum for non-professional writers who carry out writing activities in a structured manner with the main motivation of seeking positive productive activities. In general, however, this community is a reflection of the dominant-dominated binary opposition in the field of authorship.

In terms of the dichotomimasculine-feminine aspect, the community of women writers in Sidoarjo which is part of the women's writers community in Indonesia can be categorized as dominated. However, a number of their characteristics in carrying out activities exhibit the characteristics of universalist feminism related to their refusal to consider the masculine-feminine dichotomy and the dominant-dominated binary opposition in the social structure of authorship.

The results of this research are expected to be some reference and recommendation on how to view the world of authorship, which inevitably is inseparable from the existence of elements of dominated-domination. However, this research still needs to be developed further, especially in terms of authorship strategy and more elaborated description of the field of authorship.

\section{REFERENCES}

Arimbi, D. A. (2014). Finding Feminist Literary Reading: Portrayals Of Women In The 1920s Indonesian Literary Writings. ATAVISME. https://doi.org/10.24257/atavisme.v17i2.5.148-162

Bourdieu, P. (1993). The field of Cultural Production. Columbia University Press.

Bourdieu, P. (2001). Masculine Domination: Translated by R. Nice. Stanford University Press.

Denzin, N. K., \& Lincoln, Y. S. (2005). The Sage Handbook of Qualitative Research (3rd Edition). In N. K. Denzin \& Y. S. Lincoln (Eds.), The Sage Handbook of Qualitative Research (Third). Sage Publication Inc. https://doi.org/10.4324/9780203409527

Musarrofa, I. (2019). Pemikiran Pierre Bourdieu Tentang Dominasi Maskulin dan Sumbangannya Bagi Agenda Pengarusutamaan Gender di Indonesia. Kafa ah: Journal of Gender Studies, 9(1), 34. https://doi.org/10.15548/jk.v9i1.227

Ritchie, J., \& Lewis, J. (2003). Qualitative Research Practice. In Qualitative Research Practice. Sage.

Salam, A., \& Anwar, S. (2015). STRATEGI DAN LEGITIMASI KOMUNITAS SASTRA DI YOGYAKARTA: KAJIAN SOSIOLOGI SASTRA PIERRE BOURDIEU. $\quad$ Widyaparwa, $43 \quad$ No.1, 25-38. https://www.widyaparwa.com/index.php/widyaparwa/issue/view/11

Swartz, D. (1997). Culture and Power: The Sociology of Pierre Bourdieu. The University of Chicago Press. 
Widati, S. (2009). Feminisme dalam Sastra Jawa Sebuah Gambaran Dinamika Sosial. ATAVISME. https://doi.org/10.24257/atavisme.v12i1.160.83-96

Widayani, N. M. D., \& Hartati, S. (2015). Kesetaraan Dan Keadilan Gender Dalam Pandangan Perempuan Bali: Studi Fenomenologis Terhadap Penulis Perempuan Bali. Jurnal Psikologi Undip, 13(2), 149-162. https://doi.org/10.14710/jpu.13.2.149-162

Wiyatmi, W. W., \& Yogyakarta, U. N. (2008). Kiprah Perempuan Dalam Penulisan Sastra Indonesia 2000-an. Presented in Intenational Conference Woman in Public Sector, July, 16-17 2008, by Pusat Studi Wanita in Cooperation with Sekolah Pasca Sarjana Universitas Gadjah Mada, Yogyakarta, April, 1-8. https://www.researchgate.net/publication/324182262_KIPRAH_PEREMPUAN _DALAM_PENULISAN_SASTRA_INDONESIA_2000-AN 